\title{
Trust and doubt: the late medieval bishop and local knowledge
}

At best, the old habit of referring to the Middle Ages as an 'age of faith' could be seen as historical shorthand for two interpretative positions. First, and most charitably, it might be seen as explaining a supposedly unified medieval culture to a modernizing world, conveying the integral position of religion within medieval society to an age when separation of the spheres was becoming instinctive. Second, and more realistically, the idea of an age of faith was intended to draw a line between the epistemologies of the medieval world (credulous, uncurious, accepting of authority) and those of modernity (rationalist, scientific, critical). ${ }^{1}$ While the omnipresence of religion and the fact that it cannot be treated as a separate sphere have not been accepted by all medievalists (most tend to be historians either 'of religion' or 'of politics' after all), it is axiomatic for those who have thought about it more than momentarily. ${ }^{2}$ Medieval epistemology, meanwhile, has been subjected to a great deal of penetrating study. The centrality of rationalism, scientific modes of enquiry, criticism, scepticism and doubt to the fields of philosophy, theology and natural science (including medicine) is well-known. ${ }^{3}$ Epistemologies in the field of law have been less actively interrogated, but I have taken a cue from John Arnold's work on how inquisitors approached problems of evidence and areas of doubt when considering the truth of heresy allegations. They were supposed to work case-by-case with an awareness of the limitations of their knowledge. $^{4}$

\footnotetext{
1 Jaroslav Pelikan, The Christian Tradition: a History of the Development of Doctrine, III: The Growth of Medieval Theology 600-1300 (Chicago, 1978), 1-8; Susan Reynolds, 'Social Mentalities and the Case of Medieval Scepticism', TRHS, ser. 6, 1 (1991), 21-41, at 25-6. 2 Michael Prestwich, Plantagenet England 1225-1360 (Oxford, 2005), p. ix, to take a recent notable example, offers a history of England that only refers to the church 'where relevant'. ${ }^{3}$ Recent landmarks in this wide field include Katherine Tachau, Vision and Certitude in the Age of Ockham: Optics, Epistemology and the Foundations of Semantics 1250-1345 (Leiden, 1988); Dallas G. Denery II, Seeing and Being Seen in the Later Medieval World: Optics, Theology, and Religious Life (Cambridge, 2005); Christophe Grellard, Croire et savoir: les principes de la connaissance selon Nicolas d'Autrécourt (Paris, 2005); Dominik Perler, Zweifel und Gewissheit: Skeptische Debatten im Mittelalter (Frankfurt, 2006); Alex Novikoff, The Medieval Culture of Disputation: Pedagogy, Practice and Performance (Philadelphia, 2013). ${ }^{4}$ John Arnold, Inquisition and Power: Catharism and the Confessing Subject in Medieval Languedoc (Philadelphia, 2001), 78.
} 
My primary aim in this essay, however, is to move the question of doubt in medieval culture away from the study of academic disciplines and into the realm of action. The particular field of action that I am interested in is the administrative and legal work undertaken by the medieval church, for the most part overseen by bishops. The evidence in which I am bestversed comes largely from the bishops' registers of late medieval England. Similar enquiries into other bodies of evidence would certainly yield some of the same results, but there would also be differences in areas such as the precise modalities of the relevant terminology, and in the political, economic and social contexts. ${ }^{5}$ Using the English material I will delve into the language, assumptions, strategies and actions of bishops as they attempted to govern their dioceses, and of lay people's responses to this. Witness depositions in the church courts and the statements of parish representatives at visitation will be my way into lay attitudes. This will illuminate some pragmatic attitudes towards doubt and faith which can be compared to the epistemologies of the learned disciplines. ${ }^{6}$

Some of my questions concerning institutional habits of thought and utterances made within asymmetrical relations of power could easily be applied to other periods and beliefsystems as well. For this reason my approach has been informed by related work on these subjects in the social sciences and in histories of other periods. This, I hope to show, can take us further in understanding the medieval church than if we analyse it purely on its own terms. This avid intellectual borrowing must, nevertheless, be matched with due attention to the particularities of doubt and trust in later medieval western Europe. In particular, it is impossible to understand how epistemology and practice coped with doubt unless one grapples with late-medieval ideas about God and belief. Although I am not going to say anything new about how Christians faced their God, the parallels and divergences between ideas about doubt in different areas of late medieval life mean that this is a sensible place to start.

\footnotetext{
${ }^{5}$ A particularly fertile recent study - Jan K. Bulman, The Court Book of Mende and the Secular Lordship of the Bishop: Recollecting the Past in Thirteenth-Century Gévaudan (Toronto, 2008) - discusses the relationships between writing, memory, truth and proof in another specific context.

${ }^{6}$ Sabina Flanagan, Doubt in an Age of Faith: Uncertainty in the Long Twelfth Century (Turnhout, 2008), 113-5, examines the differences between doubt in secular and sacred learning.
} 
I will begin by briefly outlining some of the psychological work that doubt and faith performed in the sphere of religious belief, before going on to compare this with the two spheres of action: first, the pragmatic epistemologies of bishops as they faced the inscrutability of the social world that they governed, and second the epistemologies of lay people giving testimony as witnesses in the church courts. What were the valences of doubt, faith and knowledge in these three areas? How closely was trust in a human being related to trust in God?

\section{Religious belief}

Between the year 1000 and the Reformation the relationship between faith and doubt was configured in many different ways. The particular positions of certainty, doubt, reason, emotion, grace, intention, authority, perception, love and virtue in the constellation of faith were subtly different even amongst authors who agreed with one another, and sometimes radically different where there was substantial theological or philosophical disagreement. There were, nonetheless, a number of ideas about faith and doubt that were common enough that we can call them shared assumptions. Since my purpose is to compare the assumptions about faith and doubt underlying the actions and utterances of bishops and lay witnesses, it is pointless to ask whether any one of these was more of a realist or nominalist, more an intellectualist or a mystic. There is, of course, a great deal to say about changing conceptions of faith and doubt among learned writers. ${ }^{7}$

The common position from which all medieval theologians began their discussions of faith was that God is fixed and certain. ${ }^{8}$ Human knowledge and perception were another matter. The fall from grace had had two effects. The first was to cloud human cognitive abilities, so that God could not be seen directly. Individuals destined for salvation would, in time, come

\footnotetext{
${ }^{7}$ There are valuable introductory surveys of medieval theological positions on doubt and faith in Pelikan, Growth of Medieval Theology, 9-34; Avery Dulles, The Assurance of Things Hoped For: a Theology of Christian Faith (Oxford, 1994), 25-38; Rik Van Nieuwenhove, An Introduction to Medieval Theology (Cambridge, 2012), 62-3, 105-18, 191-4, 260-1.

${ }^{8}$ Mishtooni Bose, 'Vernacular Opinions', in Dallas G. Denery II, Kantik Ghosh, and Nicolette Zeeman (eds.), Uncertain Knowledge: Scepticism, Relativism, and Doubt in the Middle Ages (Turnhout, 2014), 239-59, at 252-3.
} 
to see God 'as if face to face' once again, but for now they had to settle for seeing 'through a glass darkly'. ${ }^{9}$ The second effect was to cause the will to falter and doubt to creep into thought about God. While for some authors in natural science and philosophy doubt was seen as a productive foundation for knowledge, in theology it was generally thought of as a human deficiency. ${ }^{10}$ To avoid doubt it was necessary to assent - through faith - to those things that were unseen or that lay beyond human reason. ${ }^{11}$ Even Abelard, regarded by many of his contemporaries and successors as an arch-rationalist, cautioned that knowledge arrived at through reason fell short of 'the knowledge of the blessed in heaven', while for late-medieval nominalists like William Ockham and Gabriel Biel whatever faith could be acquired by reason, it fell short of the full specifically-Christian faith that rested upon God's grace infusing the believer. ${ }^{12}$ Augustine's aphorism that belief 'is nothing else than to think with assent' was interpreted variously as a cognitive acceptance of God's certainty and as an emotional receptiveness to the grace that would bring faith to the individual. ${ }^{13}$

Having faith, then, meant exercising human perception, cognition and reason while recognizing their limits. It also meant - for the vast majority of people - accepting a great deal on authority. Augustine called on Christians to have faith in the witnesses sent by God. ${ }^{14}$ Hugh of St Victor responded to this in general terms by arguing that the 'simple minded in Holy Church' should believe those whose belief was more perfect (in language

\footnotetext{
91 Cor. 13:12; Hugh of St Victor, On the Sacraments of the Christian Faith, trans. Roy J. Deferrari (Cambridge, Mass., 1951), 180-2; Flanagan, Doubt in an Age of Faith, 99-103. ${ }^{10}$ Kantik Ghosh, 'Logic, Scepticism, and "Heresy" in early Fifteenth-Century Europe: Oxford, Vienna, Constance', in Denery, Ghosh and Zeeman (eds.), Uncertain Knowledge, 261-83; Dulles, Assurance of Things Hoped For, 32-4; Quinque verba, in John Shinners \& William J. Dohar (eds.), Pastors and the Care of Souls in Medieval England (Notre Dame, Ind., 1998), 134.

${ }^{11}$ The Works of Saint Augustine: On Christian Belief, ed. Boniface Ramsey (New York, 2005), 183-91.

12 Dulles, Assurance of Things Hoped For, 29, 36-8; Heiko Augustinus Oberman, The Harvest of Medieval Theology: Gabriel Biel and Late Medieval Nominalism (Durham, N.C., 1963), 6888; Flanagan, Doubt in an Age of Faith, 105.

${ }^{13}$ Saint Augustine, Four Anti-Pelagian Writings, ed. John A. Mourant and William J. Collinge (Baltimore, 1992), 222; for discussion of the influence of this aphorism see Flanagan, Doubt in an Age of Faith, 98-111.

${ }^{14}$ Saint Augustine, Trinity, ed. Stephen McKenna (Baltimore, 1963), 369-71.
} 
that would later be echoed in inquisitorial attempts to understand heretical belief). ${ }^{15}$ In Bishop Peter Quinel's 1287 pastoral Summula for the diocese of Exeter the laity were urged to 'believe what the church believes'. ${ }^{16}$ Faith was a remarkably compulsory form of voluntary certainty. Commentators frequently explained this in contrast to the uncertainty that permeated the Christian's hope in her or his own individual salvation. They could trust in God's truth, goodness and existence, but not in their own justification. For ordinary Christians faith was therefore also an admission of their own inferior position within a hierarchy of knowing. ${ }^{17}$ There might be greater merit in simple faith, believing that which could not be understood, but it was clear who should be listening to whom.

The remainder of this paper is not an explication of a discrete body of thought or writing about truth and doubt in the worlds of episcopal administration and canon law. It is an extrapolation of the attitudes embodied in actions and rhetorical statements. Some of these actions and statements reflect habits of thought that may never have been the subject of much reflection. Some, by contrast, are likely to have been intentional and crafted to suit particular purposes. We are dealing with two main types of language: written instructions sent by bishops to their subordinates and the written records of oral testimony that had been given in the church courts and before visitation tribunals. The actions under consideration are the social consequences of this language. Both varieties of language worked to their own norms and rules, and we must be mindful of these when using them as historical evidence. Bishops' letters were highly stylized; they were often based upon formularies which meant there were standard ways of writing about recognizable issues. But this still left room for intention and consideration. More importantly, there was as

\footnotetext{
${ }^{15}$ Hugh of St Victor, On the Sacraments, 168-70, 173-4; Vincent of Spain in Constitutiones Concilii quarti Lateranensis una cum Commentariis glossatorum, ed. A. Garçía y Garçía, Monumenta luris Canonici Series A: Corpus Glossatorum, 2 (Vatican, 1981), 291 ('Credimus quod homines secte illius boni sunt'); Lucy Sackville, Heresy and Heretics in the Thirteenth Century: the Textual Representations (Woodbridge, 2011), 97-8, 117-21, 129.

${ }^{16}$ Councils and Synods with other Documents relating to the English Church II: A.D. 12051313, ed. F. M. Powicke and C. R. Cheney (Oxford, 1964), 1063.

${ }^{17}$ Berndt Hamm, The Reformation of Faith in the Context of Late Medieval Theology and Piety (Leiden, 2004), 159-62; Michel de Certeau, 'Une pratique sociale de la différence: croire', in Faire Croire: Modalités de la diffusion et de la réception des messages religieux du XIle au XVe siècle (Rome, 1981), 363-83, at 364-5, 373-5.
} 
much meaning in formulae as there was in studied originality. ${ }^{18}$ Written records of oral testimony have generated a huge volume of historiographical reflection and disagreement. Witness statements may not be the 'language of everyday life', but they were often faithful inscriptions of what people said in court. They are, as John Arnold has said of inquisition records, utterances produced by the encounter with power, but this is nonetheless a historically interesting interaction. We just need to be mindful that church courts, visitations and inquisition tribunals were not Mass Observation. ${ }^{19}$ We can use bishops' letters and recorded oral testimony to find out about attitudes to doubt held by an individual or agreed among a wider group.

\section{The costs of local knowledge}

One element in the bureaucratization of the church between 1100 and 1300 was a changing attitude towards local knowledge. As diocesan government intensified and disputes over rights and judgements became more frequent, bishops put more and more of a premium upon the acquisition of reliable local knowledge. Who was the rightful patron of this living? To which parish should tithes be paid from that piece of land? What would the repairs to this or that rectory cost and who was going to pay? Was the nominee for some benefice or other a person of good character? Had this man and that woman known how closely they were related at the time of their marriage? Were the clergy here and there performing the tasks that were expected of them? Bishops acquired their practical knowledge of such people and things in their dioceses by asking the locals.

But finding things out by asking the locals came at a cost. In fact, much of what we think of as the institutional church was shaped by a never-ending dialectic of the 'costs' incurred by

\footnotetext{
${ }^{18}$ See particularly here the work of Michael Burger: 'Sending, Joining, Writing and Speaking in the Diocesan Administration of Thirteenth-Century Lincoln', Mediaeval Studies, 55 (1983), 151-82; 'Bishops, Archdeacons and Communication between Centre and Locality in the Diocese of Lincoln, c. 1214-1299', in Peter Coss and S. D. Lloyd (eds.), Thirteenth-Century England V (Woodbridge, 1995), 195-206; Bishops, Clerks, and Diocesan Governance in Thirteenth-Century England: Reward and Punishment (Cambridge, 2012).

19 John Arnold, 'Inquisition, Texts, and Discourse', in Caterina Bruschi and Peter Biller (eds.), Texts and the Repression of Medieval Heresy (Woodbridge, 2003), 63-80, penetrates a dense and interesting debate.
} 
information problems and the costs of their solutions. ${ }^{20}$ These costs were not necessarily monetary. They could involve the loss of certainty and the acceptance of doubt. In a hypothetical situation of perfect ignorance about the condition of his parishes a bishop might possess absolute certainty as to what had to be done. This may be one reason why episcopal registers so often record a flurry of activity in the first few months of an episcopate. But as soon as he began to make himself better acquainted with local conditions he paid for knowledge with the loss of certainty. All information had to be taken on trust. From the mid-thirteenth century onwards bishops began referring to their local informants as 'trustworthy men': viri fidedigni. ${ }^{21}$ Taking things on trust meant living with doubt. Had the locals told the truth? Would their testimony stand the test of time? Had the inquest been rigged by some powerful family? In facing such doubts bishops were no different from the personnel of all historic and contemporary governing organizations, though the precise nature of the information problems they faced was, of course, particular to their situation.

Bishops had to live with doubt, but they were content to do so. This had much to do with their concept of trustworthiness. Before examining how trustworthiness figured in the solutions and the problems of the informational church, it is worthwhile pausing to reflect on the nature of those problems. What were the costs of information?

In the Critique of the Philosophy of Right, Marx wrote that bureaucracy is 'a circle from which no-one can escape. Its hierarchy is a hierarchy of knowledge. The apex entrusts the lower circles with insight into the individual while the lower circles leave insight into the universal to the apex, so they deceive each other reciprocally. ${ }^{22}$ This mutual deception need not be intentional. It could, and often did, easily arise from the difference in culture between the top and the bottom of a hierarchy of knowledge. It is evident that the medieval church is amenable to analysis in these terms. Bishops had to cross an enormous cultural divide in order to trust the laity to provide useful information. Sometimes the chasm was unbridgeable and the locals just did not understand what really mattered in the

\footnotetext{
${ }^{20}$ Ian Forrest, 'Continuity and Change in the Institutional Church', in John H. Arnold (ed.), The Oxford Handbook of Medieval Christianity (Oxford, 2014), 185-200.

${ }^{21}$ These themes will be fully explored in my forthcoming book Trustworthy Men: How Inequality and Faith made the Medieval Church.

${ }^{22}$ Karl Marx, Selected Writings, ed. David McLellan, second edition (Oxford, 2000), 37.
} 
world of canon law and government. To give just one example, in 1346 the bishop of Hereford ordered an inquest into the patronage of Sibdon chapel in Shropshire. He gathered information from local 'trustworthy men'. But they failed to understand the specifics of what they were being asked to do. They reported that the chaplain had a customary duty to celebrate mass twice a day and bemoaned the fact that the chapel could only be served three days a week; they identified the current chaplain; they described how a previous lord of Sibdon had endowed the chapel. But they did not say who had last presented to the chapel. Because of this the inquest was deemed to have 'failed' and the bishop's official, a university graduate and experienced administrator, was sent to repeat the exercise. ${ }^{23}$ The men on the spot knew how to acquire local knowledge, but either they were so far removed from the culture of episcopal administration that they missed the point of the inquest, or they set out intentionally to deceive the bishop. They provided lots of pertinent information, but failed on a technical point: actually spelling out who the patron was. $^{24}$

There were many asymmetries of knowledge and information in the medieval church, and so perhaps the Shropshire case should not surprise us. The clergy were a group marked out by specialist knowledge and the skills of reading and writing, as well as by the ritual of ordination; graduates and the higher clergy practised a literacy that was much more sophisticated than the pragmatic reading and documentary awareness of the average parish priest; legal rules of evidence were far narrower than everyday concepts of knowledge, and required a learned, or practised, precision. In Marx's terms knowledge of the individual and knowledge of the universal could be mutually unintelligible. But in fact failed inquests were rare, or at least were not often recorded in bishops' registers. So we should perhaps imagine that it was normal for these things to proceed relatively smoothly. Most reports of inquests are careful itemizations of the facts adhering closely to the wording of the bishop's original instructions. Clearly a great deal depended upon the agents chosen by the bishop. If they were inexperienced or unversed in the cultures of law and administration, they might

${ }^{23}$ Registrum Johannis de Trillek, Episcopi Herefordensis, A.D. MCCCXLIV-MCCCLXI, ed. J. H. Parry, CYS, 8 (London, 1907), 39.

${ }^{24}$ The need for technical knowledge and precise adherence to rules figured as part of Weber's ideal-type of bureaucratic administration, particularly associated with officials appointed by superior powers: Max Weber, 'Bureaucracy', in Hans H. Gerth and C. Wright Mills (eds.), From Max Weber: Essays in Sociology (London, 1991), 201. 
perform their tasks diligently, but in vain. Most of the time, however, this problem was limited by the ability of the bishop's agents to translate the universal into the local and vice versa. Many episcopal letters commissioned a local cleric and a member of the bishop's household to act together. Many parish priests were graduates themselves, or had built up a wealth of experience dealing with the business letters of their superiors. For the most part then, bishops assumed that the recipients of their letters would know what to do. What remained problematic was the almost complete inability of the bishop to know how much was being kept from him and not communicated at all.

The concentration of power in the hands of the bishop (exemplified by the phenomenon of 'reserved cases' that only he could judge) and his reliance upon good information meant that his capacity for action could be severely hampered if he were starved of information. Bottlenecks of information could be created by the failure of officials at different levels to pass material either upwards or downwards. ${ }^{25}$ However, even the supposedly characteristically-modern condition of 'information overload' also affected medieval administrators. The most studied examples are Domesday Book of 1086 and Edward I's Hundred Rolls of 1279-1280, both of which produced so much information that they were not put to much use, but many church visitation records could be considered in the same light. ${ }^{26}$ A great deal of information was merely recorded and never followed up.

Geography could also throw up significant barriers to the effective retrieval of information. The documentation surrounding visitations demonstrates this very well. Multiple groups of parish representatives had to be organized to appear at a particular time and place, each having submitted written reports in advance. Frequently these groups did not appear, or the information was not available all in one place, and so cases trailed along in the visitor's wake, dragging parishioners and litigants, letters and reports from place to place. This may not have made for efficient decision-making. But it did bring bishops closer to localities. They toured the parishes of their dioceses in order to collapse the geographical distance that separated them from their flocks; they travelled their estates in order to be a visible

\footnotetext{
${ }^{25}$ Barry Barnes, The Elements of Social Theory (London, 1995), 204.

${ }^{26}$ There is no consensus on the much-studied Domesday Book, but the case for its utility over its symbolism has not been proven: David Roffe, 'Domesday Now', Anglo-Norman Studies, 28 (2006), 168-87; Sandra Raban, A Second Domesday? The Hundred Rolls of 127980 (Oxford, 2004).
} 
presence among the gentry and nobility living far from cathedral cities. They were aware of the information cost imposed by distance and they tried to do something about it.

This worked pretty well when something had happened that affected a single place and the bishop or his commissioner arrived in person to supervise an inquest. But when the information needed to resolve some issue was harder to locate, the costs of retrieving it could escalate, both in the sense of being more expensive and in the degree of faith one could place in the truth or stability of the information. For example, when in 1320 Andrew le Boteler claimed benefit of clergy after being charged with murder, the archbishop of York ordered an inquest into his life and character, his 'name and opinion', in his home region. Was either his guilt or any previous crime he might have committed well-known there? The problem was that Le Boteler had moved around a great deal and there was no question of sending a commissioner to empanel the trustworthy men of a single parish. Instead Archbishop Melton called for 'trustworthy clerics and laymen ... from the places where he is most well-known', and these were scattered across Nottinghamshire and the East Riding. Somewhat unsurprisingly nothing definitive emerged from these attenuated efforts, and the only option after six months was to advertise Andrew le Boteler's desire to undergo purgation and see if 'objectors' came forward. ${ }^{27}$ This was an unsatisfactory and inferior means of testing for truth. The verdict would come from the suspect's friends and supporters rather than a group of well-informed trustworthy men.

The most significant cost attached to information, in terms of the effort that could potentially be expended, was the difficulty involved in assessing trustworthiness. ${ }^{28}$ So what did medieval bishops mean when they referred to 'trustworthy men'? The fidedignus had for centuries been a reasonably common way of describing the apostles, saints and martyrs of the church who were direct witnesses to God's truth. ${ }^{29}$ They had not merely believed;

\footnotetext{
27 The Register of William Melton Archbishop of York 1317-1340, ed. Rosalind M. T. Hill, David Robinson, Reginald Brocklesby and T. C. B. Timmins, 5 vols., CYS, 70, 71, 76, 85, 93 (Torquay, 1977-8; York, 1988; Woodbridge, 1997-2002), iv.35-6, 42-3, 63-5. ${ }^{28}$ David Good, 'Individuals, Interpersonal Relations and Trust' in Diego Gambetta (ed.), Trust: Making and Breaking Cooperative Relations (Oxford, 1988), 42.

${ }^{29}$ For example Theodoret of Cyrus (393-466) and Bede (672-735) praised the gospel authors as 'trustworthy': Theodoretus Cyrensis, Philotheus, PL 74, col. 797; Bede, Super acta apostolorum expositio, PL 92, col. 939. This usage was current in twelfth-century theological commentaries: Biblia Latina cum glossa ordinaria: Facsimile Reprint of the Editio Princeps
} 
they had seen the Lord in one way or another. Such trustworthy witnesses to God's truth were precisely the kind of authorities that the 'simple minded in Holy Church' were enjoined to believe. ${ }^{30}$ They possessed knowledge and understanding that could not be attained by ordinary people. To apply such a term to laypeople - peasants - in the parishes was therefore something of a departure from the language and the epistemology of the church in the first millennium. If faith should only be placed in that which was certain, like God, or in those who had been granted a privileged vision of divinity - the saints - how was it that bishops could place their trust - their fides (faith) - in peasants?

The answer is that the need for such local knowledge as would support the governance of the church created an imperative for a new epistemology and a new attitude to faith and doubt. The act of trust was no longer determined by the fixity of the object (God) or by the virtues of the witnesses, but by the bishop's attitude to risk. Let us consider for a moment the interplay of knowledge and trust in the cases we have been examining. Bishops did not, nor could they ever hope to, know the laymen in their dioceses in a meaningful way that would enable them to choose only the most honest and truthful individuals to be their informants. Moreover, it would have been prohibitively costly, in terms of time and effort, to attempt such a calculation. The economic sociologist Douglass North has made the general point that the people one deals with in any given situation might possess desirable attributes to varying levels, but ' $[\mathrm{t}]$ he measurement of these levels is too costly to be comprehensive or fully accurate' ${ }^{31}$ So what is to be done? Since uncertainty and risk add costs to all transactions, it is necessary to find a way of reducing these costs. ${ }^{32}$ How did bishops reduce the cost of doubt?

Adolph Rusch of Strassburg 1480/81, (Turnhout, 1992), commentary on Acts 6:5, 11:24 and 1 Timothy 1.11; Peter Lombard, The Sentences, trans. Giulio Silano, 4 vols. (Toronto, 2008), iii.101.

${ }^{30}$ Hugh of St Victor, On the Sacraments, 168.

${ }^{31}$ Douglass $\mathrm{C}$. North, Institutions, Institutional Change and Economic Performance (Cambridge, 1990), 29.

32 John Dunn, 'Trust and Political Agency' in Gambetta (ed.), Trust, 73-93, at 73; Oliver Williamson, 'The New Institutional Economics: Taking Stock, Looking Ahead', Journal of Economic Literature, 38 (2000), 595-613; idem, 'Calculativeness, Trust, and Economic Organization', Journal of Law and Economics, 36 (1993), 453-86. 
German sociologist Niklas Luhmann has observed that 'the complexity of the future world is reduced by the act of trust' ${ }^{33}$ Economists often say that trust is a means of reducing transaction costs. ${ }^{34}$ Notwithstanding the differences of language and purpose, this seems to be precisely the attitude to doubt, risk and the future adopted by medieval bishops. In 1309 Walter Reynolds, bishop of Worcester, called for an inquest of trustworthy men to find out which rectors of parish churches in the deanery of Warwick had failed to be ordained priest within a year of their appointment. It was commonplace for men not yet ordained priest to be put in charge of churches. Six rectors were reported, of whom three went on to be ordained even though they did not have their papers in order. They merely had to swear that they had not been in their churches more than a year and this allowed them to be ordained 'at their own risk'. That is, they had to accept that if their ordination was proved illegal in future it would be their problem and not the bishop's. ${ }^{35}$ There must have been reasonable doubt. In this case and many others like it we do not know whether the inquiry exposed all offenders or merely those who were unpopular with some portion of their parish community. But we should not be too dismayed since we share our ignorance with the bishops who commissioned such inquiries. The trust necessary to secure information was paid for with the shrugging acceptance that it might be incomplete or misleading. Reduced costs were accompanied by sub-optimal, but acceptable, outcomes.

Two years later Reynolds processed the case of John Mauduyt, a cleric who had received minor orders without a hitch, but had then been ordained a priest without having a 'title', that is a benefice in which to serve. His mistake 'was revealed to him through the prudence of another' and he went to Avignon to seek papal dispensation. The pope wrote to the bishop that since Mauduyt had actively sought to correct the fault he could be forgiven so long as the facts were as reported and there was no lingering sentence of excommunication. The bishop forced Mauduyt to abstain from all meat, eggs and dairy foods for a month, in the meantime launching an inquiry through trustworthy clerics and laymen. The inquiry was

\footnotetext{
33 Niklas Luhmann, Trust and Power (Chichester, 1979), 20, 24-30.

${ }^{34}$ Partha Dasgupta, 'Trust as a Commodity', in Gambetta (ed.), Trust, 49-72, at 64; Williamson, 'Calculativeness, Trust, and Economic Organization'. ${ }^{35}$ The Register of Walter Reynolds Bishop of Worcester 1308-1313, ed. Rowland Alwyn Wilson, Dugdale Society Publications, 9 (London, 1928), 4-5, 9, 32-3. Diego Gambetta, 'Can we Trust Trust?', in idem (ed.), Trust, 213-37, at 218-9 argues that trust always implies a degree of ignorance and the potential for being deceived or disappointed.
} 
satisfactory and Mauduyt was recognised as a priest. The key fact that needed local verification was whether Mauduyt had 'knowingly' obtained false documentation. It is hard to imagine how this could be corroborated except by his own testimony, or perhaps from highly subjective and retrospective inferences drawn from his behaviour and bearing, but the bishop and the pope seemed happy with this degree of doubt. ${ }^{36}$ As in the previous case, subsequent conflicting information might have changed matters. The authorities were trusting in the absence of knowledge. As Diego Gambetta wrote in 1988, trust is a peculiar belief predicated not on evidence but on the lack of contrary evidence' ${ }^{37}$

In these and many hundreds of similar cases it may look as though bishops and popes were acting irrationally. They had no idea whether their trust had been misplaced or not. Were they not making a mockery of the language of faith? Was it making a mockery of them? If we were to measure their faith in fallible parishioners against the explanations of faith given by later medieval theologians, this might seem to be the case. Whereas the object of faith God - was certain, the object of a bishop's trust - the 'trustworthy man' - was not. Placing faith in local laymen attributed to them similar qualities to those embodied in God, such as stability and constancy. But the doubt involved in these contrasting attributions of faith was on a different plane. Doubt about God was a personal psychological defect, a product of man's fallen state, whereas doubt about local testimony was a product of a more politic circumspection.

There was a strong instrumental rationality about a bishop's trust in local testimony. When Bishop Reynolds trusted the locals despite the impossibility of knowing whether he had been fully informed, and when he accepted the word of delinquent priests despite a lack of strong evidence to exonerate them, he was acting rationally. Rationally, that is, insofar as he had a sound understanding of the benefits that trusting would bring to him and to the church. Reynolds had decided that to trust and accept doubt was better than to attempt a precise calculation of probabilities. ${ }^{38}$ He was working within tolerable levels of uncertainty,

\footnotetext{
${ }^{36}$ Register of Walter Reynolds, 83.

37 Gambetta, 'Can we Trust Trust?', 234.

${ }^{38}$ Luhmann, Trust and Power, 26, 88. The instrumental rationality on display here is consonant with the ends-means reasoning described by David D'Avray, Rationalities in History: a Weberian Essay in Comparison (Cambridge, 2010), 59-65. D'Avray argues that institutions frequently work to a hierarchy of values in which the overt value rationality (in
} 
knowing that to have pursued the truth remorselessly would have been both costly and counterproductive. A degraded priest would have been a scandal. The prohibitive cost of perfect information meant that institutions had to find ways of living with incomplete information. 'Perfection' is of course impossible in the acquisition of knowledge about the social world and so this cost should be imagined as infinite. This could have presented a huge problem if churchmen had not had a pragmatic attitude towards truth. By trusting, and by accepting doubt, bishops could 'shift the problem into a realm where it [could] be mastered more effectively'. ${ }^{39}$ Accepting incomplete information did not make the church less powerful. It was done in the pursuit of power. Tolerating doubt made local society more 'legible', not less. Local knowledge accepted with judicious doubt brought power, whereas perfect knowledge of the social world would have overwhelmed the institution with its unbounded variety, its illegibility, unconformity, and strangeness. ${ }^{40}$

Although acknowledged as being imperfect, episcopal information about the social world was idealized as a form of truth. Indeed, this was the stated object of all church inquiries in our period. However, truth, like trust, was not something thought only to exist in some utopian place where all doubt had been extinguished. Not having certain knowledge of God or any sense-evidence of His existence or goodness, medieval Christians were expected nonetheless to place their trust in Him and find certainty in assenting rather than knowing. God could not be separated from truth, and neither He nor it could be known by human faculties alone. Truth, like God, was something in which one had to have faith, confident of its existence in some rather unlikely places. Truth might be obscured, but it was still there.

Trustworthy men were expected to tell the truth. This was often spelt out in the instructions for visitation that bishops sent to their officers locally. In 1283 Archbishop

this case the value placed upon trust) can seem to be contradicted by instrumental reasoning; yet if one attends to the ends that the instrumental actions are serving, a higher set of values can be discerned. In this case the 'ends' served by lip-service to trustworthy testimony were the dignity of the clerical estate and the smooth functioning of church administration.

${ }^{39}$ Luhmann, Trust and Power, 37.

40 James Scott, The Art of Not Being Governed: an Anarchist History of Upland South East Asia (New Haven, 2009), passim; idem, Seeing like a State: How Certain Schemes to Improve the Human Condition Have Failed (New Haven, 1998), 64-73; John Law, 'Power/Knowledge and the Dissolution of the Sociology of Knowledge' in idem (ed.), Power, Action and Belief: $a$ New Sociology of Knowledge? (London, 1986), 1-19, at 10. 
Pecham wanted trustworthy men through whom he could 'best inquire into the truth'; in 1324 Bishop Orleton of Hereford wanted trustworthy men who would tell the truth in the proper way ... about those things asked of them that demand to be caught in the net of correction'; also in 1324 Archbishop Melton of York asked for parishioners who would say 'what they know to be true concerning those things required of them' ${ }^{41}$ Upon receiving information they regarded as meeting these requirements bishops might claim that their evidence was based upon the 'testimony of trustworthy jurors [which] we fully accept to be true' ${ }^{42}$ Truth, in these formulations, was something to be accepted rather than known beyond doubt. Bishops seem to have admitted the possibility of disagreement. As the twentieth-century liberal philosopher Michael Polanyi succinctly put it, the 'attribution of truth ... is a fiduciary act'. ${ }^{43}$ That is to say, in order to mitigate the costs of knowledge, truth must be taken on trust.

\section{Belief and legal testimony}

When bishops placed faith in lay parishioners their trust was insured against the impossibility of objectivity by the weight of institutional power. They could operate effectively if they received reliable information most - and not necessarily all - of the time. Their expression of faith in local men was tinged with doubt about what they said. And when lay people in turn provided information to churchmen, they also had to navigate the bounds of human rationality and perception, and they likewise did so in words that borrowed from the language of religious belief.

\footnotetext{
${ }^{41}$ Registrum Johannis de Pontissara Episcopi Wyntoniensis A.D. MCCLXXXII-MCCCIV, ed. C. Deedes, 2 vols., CYS, 19, 30 (London, 1915-24), 278-9; Registrum Ade de Orleton, Episcopi Herefordensis, A.D. MCCCXVII-MCCCXXVII, ed. A. T. Bannister, CYS, 5 (London, 1908), 287; Register of William Melton, i.134-5. For other examples see The Register of John de Grandisson, Bishop of Exeter (A.D. 1327-1369), ed. F.C. Hingeston-Randolph, 3 vols. (London, 1894-99), 639, 1021, 1215.

${ }^{42}$ Registrum Hamonis Hethe, diocesis Roffensis, A.D. 1319-1352, ed. C. Johnson, 2 vols., CYS, 48-9 (London, 1948), 173-4; similar at 174-5.

${ }^{43}$ Michael Polanyi, Personal Knowledge: Towards a Post-Critical Philosophy (London, 1958), 294.
} 
The interplay between faith and doubt was most commonly enunciated in the language of belief. The constitutions of reforming councils and synods from the thirteenth-century onwards encouraged Christians to learn the credo and the articles of faith. The submission of the will, the cognitive assent to authorized teaching, and the attitude of receptiveness to God's grace were - idealistically - encapsulated in the moment when the Christian uttered the words 'I believe'. But there were other things in which people could believe. I do not mean alternative systems of religious belief, but belief as a commonplace epistemological act. One such act that affected the church and other Christians in important ways was the assertion of belief made by witnesses in the church courts, at visitation, and before inquisition tribunals.

There was substantial common ground between theology and practical epistemology, especially the fact that faith or belief denoted a notion held on trust; that is, trust in an authority, in received wisdom, in natural principles, or in one's own assumptions. But while trusting delineated common ground, trusting in what was an important point of difference. The 'I believe' of the creed had a very different meaning from the 'I believe' of the courts. Whereas the believer reciting the creed was meant to resign their doubts and submit to the certainty of God and the authority of the church, the witness in court who said 'I believe' was placing trust in her or his own suppositions. But even this was a highly conditional kind of trust.

Assertions of belief were especially common in witness statements made for the church courts, and in the reports that trustworthy men submitted to visitations. For example, the deposition book of the bishop of London's consistory court between 1467 and 1476 is littered with the phrase 'as he or she believes' (ut credit). ${ }^{44}$ This short but ubiquitous and meaningful phrase could be thought of as a firm assertion of knowledge, but it also contained the grounds for its own cautious qualification. The deponent may well have felt their evidence to be true so far as they were concerned. They had confidence in their own judgement and perception. ${ }^{45}$ At the same time, this was a way of admitting the possibility

\footnotetext{
${ }^{44}$ London, London Metropolitan Archives, DL/C/0205, passim.

${ }^{45}$ Polanyi, Personal Knowledge, 267 argued that all claims to knowledge must rest on certain unexamined assumptions, whether they concern God or an individual's belief about him- or herself.
} 
of error and protecting oneself against the consequences of being proved wrong. In this, at least, the cautious witness was following closely Hugh of St Victor's aphorism that belief is 'a kind of certainty of the mind in things absent, established beyond opinion and short of knowledge. ${ }^{46}$ The witness was in a position that was at once privileged (telling the court what he or she knew) and subordinate (restricted to speaking about the facts of the case), which made cautious assertions of certainty the most appropriate form of utterance.

It is hard to discern exactly where along the spectrum between opinion and knowledge belief was thought to exist in any given instance. Statements of the type 'I believe' and 'I know' may well, in fact, do more to describe the feelings of the witness than the status of the evidence. Moreover 'I believe' could be uttered with any inflection, steering it more towards doubt in one situation, more towards certainty in another. This is just one of the elements of speech that we cannot access as historians. Needless to say, such ambiguities must have given lawyers many opportunities to challenge witnesses' statements.

The trustworthy men reporting to several late medieval visitations adopted the language of belief with regard to everything from commonplace sexual offences to politically tricky issues of authority. In Hereford diocese in 1397 the parish representatives of Norton had said that Sybil Gyfker fornicated with a clergyman called John Matthew or John Smith, 'or so they believed'. They did not know his name for certain, though he did live in Norton. Meanwhile the parishioners of Weobley said that Katherine Ondys was pregnant and it was not known (nescitur) by whom, but it was believed (creditur) to be the rector of Sarnesfield; the parishioners of Culmington in Shropshire reported two couples - Jankyn Tasger and Katherine 'whom he keeps as his wife', and Matthew Tailor and Philippa Bakon - for fornication because they believed both pairs were unmarried. They also reported Isabelle of Wales for fornicating with a Welshman whose name was not known, though they believed him to be Jankyn Tailor. ${ }^{47}$ In Lichfield sometime in the 1460 s the lay representatives of Stow Street and Tamworth Street said that they did not 'know' who had made Margaret Seyne pregnant, but they 'believed' that it had been William Harper; at Saddler Street they reported that the priest William Heyth had suspiciously gone to the house of Emmota Garnet with a woman called Helena Puella ('the girl'?). There, so they believed, he 'knew'

\footnotetext{
${ }^{46}$ Hugh of St Victor, On the Sacraments, 168.

${ }^{47}$ Hereford, Hereford Cathedral Archives, 1779, fos. 2v, 3v, 22r.
} 
her (cognovit eam). They were heard carousing and drinking later than was decent (extra tempus honestum). ${ }^{48}$ In this carefully constructed report the closing of the brothel door set a seal upon the boundary between knowing and believing, but the level of detail suggests they were in no doubt themselves as to what had occurred.

Sometimes more subtle judgements were wrapped in the guarded language of belief. At Ruardean in Gloucestershire in 1397 it was said that Nicholas Cutler had told people how the spirit of his dead father went about the parish at night while Nicholas kept watch at the tomb. The trustworthy men said that this was to the great scandal of the Christian faith, 'as they believed'. Their final words were both an assertion of their firm views on Christian propriety, and an acknowledgement that the bishop was the only person with the authority to decide whether this was really orthodox or not. They were not qualified to judge, only to believe. Another matter of authority troubled the parish representatives of Waterdine, Shropshire in the same year. They claimed that they were customarily served by a secular priest although their church was appropriated to Wenlock Priory. But the prior had foisted a parish chaplain upon them, taking away their vicar and his income 'without sufficient authority, as they believe'. They wanted the visiting bishop to demand that the prior show his authority. This was caution in the face of possible future documentary proof. The parishioners knew that documents were what secured rights, and that there should have been an episcopal 'ordination' made for the vicarage at the time when it was first appropriated to Wenlock. Without a copy of the document, and recognizing that this was an area where custom and memory alone would not do, all they could do was assert their cautious belief. ${ }^{49}$ In the North Riding in 1428 the parish representatives of Farnham took a slightly different approach, but it amounted to the same thing. They said that William Smyth and Alice Verte had married and then separated because of his impotence, but they 'doubted' whether the separation was canonically sanctioned. ${ }^{50}$ Canonical sanction was something that only a bishop or the pope could grant, and so the parishioners were right to express caution.

\footnotetext{
${ }^{48}$ Lichfield, Lichfield Record Office, D 30/9/3/1, fos. 23r, $26 r$.

${ }^{49}$ Hereford, Hereford Cathedral Archives, 1779, fos. 6v, 24v.

${ }^{50}$ York, Borthwick Institute, Register 19 (John Kempe), fos. 211v-213r.
} 
The men who represented parishes at visitation were thus aware of the huge power imbalances between them and their visitors. In this context belief was the perfect vehicle for expressing opinions and doubtful information. Belief brought with it huge implications of trust in authority and strength of judgement derived from faith in God. These men knew how to couch complaints so as to demand a bishop's attention. But assertions of belief also played mischievously on the weaknesses of human perception which, when coupled with the bishop's superior legal standing and the parishioners' subaltern status, became a way for a line to be drawn between what the locals were qualified to say and the establishment of fact and law by proper authorities.

In treading this line the representatives of both the parish and the institutional church were aware of a rule to which most visitation proceedings conformed. Insofar as canon law commentators wrote anything about visitation - and it was not much - they were clear that the reports of the laity constituted fama, that is opinion or belief, and that only a judge could establish facts. In spite of this it was widely accepted that the articulation of fama as a form of provisional knowledge set in train a process whereby report became fact. ${ }^{51}$ With certain types of 'continuous fact' - things within the competency of collective remembrance, such as boundaries or ownership - fama had long been admissible. Gradually, between 1100 and 1250, fama was also allowed to play a part in establishing more transient facts such as whether a marriage had taken place. ${ }^{52}$ In cases of this sort, where bishops were dependent upon local knowledge, the boundary between fama and fact was impossible to maintain. Local knowledge was not only valuable to bishops; they would have been unwise to reject it. For the most part bishops accepted the reports of trustworthy men and so for all that they constituted 'mere' fama or belief, they arrived on

51 Thelma S. Fenster and Daniel Lord Smail (eds.), Fama: the Politics of Talk and Reputation in Medieval Europe (Ithaca, 2003); Charles Donahue, 'Proof by Witness in the Church Courts of Medieval England: an Imperfect Reception of the Learned Law', in M.S. Arnold et al. (eds.), On the Laws and Customs of England: Essays in Honor of Samuel E. Thorne (Chapel Hill, NC, 1981), 127-58, at 131.

52 Ian Forrest, 'The Transformation of Visitation in Thirteenth-Century England', Past and Present, 221 (2013), 3-38, at 23-27; Donahue, 'Proof by Witness in the Church Courts of Medieval England', 136-40. 
the bishop's desk with the weight of local knowledge behind them, pushing them inexorably down the path towards accepted facts, alleged certainty and acknowledged truth. ${ }^{53}$

\section{Conclusions}

Across the learned disciplines of theology, philosophy, medicine and law, the twelfth and thirteenth centuries saw new distinctions being drawn between what was, and what was not, knowable by human faculties. Faith, belief, trust and doubt were coming to describe the liminal spaces within hierarchies of knowledge. In law fama was being distinguished from fact; in philosophy doubt was seen as an impetus for continuing enquiry; in medicine the limits of observation and experiment were being explored; while amongst theologians discussion of belief focussed upon the limits of reason and its differentiation from faith.

In the two spheres of action that have been the subject of this paper-episcopal governance and lay assertions of local knowledge - this concern with the limits of certainty and the ubiquity of doubt were also of fundamental importance. I have tried to extrapolate assumptions about trust and doubt from the language and the actions of bishops and lay people within these frameworks. When we compare their assumptions with the conventional ideas about faith common to most theological writers there are some important similarities, but also some equally important points of difference. The similarities are most apparent at the level of language, with bishops placing faith in local men worthy of their trust and lay witnesses asserting the difference between what they believed and what they knew. In both spheres the language of faith, trust or belief pertained to that which lay beyond immediate comprehension: this was as true of events not witnessed in person and of the mysteries of local custom as it was of God. Furthermore, just as God was certain,

\footnotetext{
53 The tendency for opinion to be converted into fact, and for judges to play only a minimal role, has also been noted by historians of the English common law juries of presentment and trial: John H. Langbein, 'Jury Influence on Conceptions of the Judiciary', in Paul Brand and Joshua Getzler (eds.), Judges and Judging in the History of the Common Law and Civil Law: from Antiquity to Modern Times (Cambridge, 2012), 67-82, at 69-72; Mike Macnair, 'Vicinage and the Antecedents of the Jury', Law and History Review, 17(1999), 537-90, at 547, 589-90; Morris S. Arnold, 'Law and Fact in the Medieval Jury Trial: Out of Sight, Out of Mind', American Journal of Legal History, 18 (1974), 267-80, at 278.
} 
bishops and lay witnesses tended to think of the objects of their trust as certain, if only for pragmatic reasons arising from the need for action.

But the differences are arguably more striking. The explicit placement of faith in lay frequently peasant - informants in order to gain knowledge about the transient material and social world would have shocked earlier generations for whom faith was only worthy of being placed in God, Christ and the exceptional men and women who had been permitted direct knowledge of the divine. What is more, while bishops clearly thought reports from 'trustworthy men' were better than mere opinion, it is far less clear whether they also thought - as did Hugh of St Victor about religious faith - that those reports fell short of 'knowledge'. They treated them as knowledge; they had to. Moreover, lay expressions of belief made in witness depositions and visitation reports may have traced the boundary between the seen and the unseen in a way that was compatible with the epistemology of faith, but their faith was not being placed in God. Witnesses trusted their own suppositions. This is not how the 'simple minded' of the church were urged to think about God.

These convergences and divergences in attitudes towards doubt and uncertain knowledge bring us back to one of the outstanding questions about medieval culture: how should we conceptualize the relationship between religion and everything else? Of course the Middle Ages were not an 'age of faith' in the sense that everyone shared an equal and unquestioning belief. We know too much to fall into that fallacy. But can everything be reduced to Christianity in the way that Richard Southern arguably did in treating Christendom as a 'compulsory society' (and in the way that some students new to medieval history, sensing the importance of religion in the period, can sometimes do as well)? ${ }^{54}$

There is no doubt that religious modes of thought permeated all others. But this is not the same as everything being reduced to the religious. Famously, Augustine had explained faith in God by a series of analogies with human belief in other unseen things, such as our own minds and the feelings of friends. ${ }^{55}$ We cannot perfectly know the intentions of another person towards us, but we trust that our trust in them is reciprocated: without this, Augustine wrote, human society would fail. But these analogies can also serve to remind us

\footnotetext{
${ }^{54}$ Richard W. Southern, Western Society and the Church in the Middle Ages (Harmondsworth, 1970), 17.

${ }^{55}$ The Works of Saint Augustine: On Christian Belief, 184-6.
} 
that the patterns of thought necessary for belief in God were never confined to that objective. Religious faith was explained in terms that acknowledged the importance of doubt, belief and trust in other spheres of life; spheres that had their own imperatives. The need for doubt and the need for trust in knowing the social world were, in the later Middle Ages, being reframed in the language of religious faith. But they were not subsumed by it. Practices of faith, belief, trust and doubt were therefore connected at the epistemological level, but separated by their theologies. Whether or not, in the face of doubt, to trust God, trust the people, or trust oneself were questions whose answers could be incompatible. 